\title{
Determinants of Entrepreneurial Intention of Business Students in Bangladesh
}

\author{
Md Reaz Uddin ${ }^{1} \&$ Tarun Kanti Bose ${ }^{1}$ \\ ${ }^{1}$ Business Administration Discipline, Khulna University, Khulna, Bangladesh \\ Correspondence: Tarun Kanti Bose, Business Administration Discipline, Khulna University, Bangladesh. Tel: \\ 880-191-145-1044. E-mail: tarunboseku@gmail.com
}

Received: September 16, 2012

Accepted: November 15, 2012 Online Published: November 28, 2012

doi:10.5539/ijbm.v7n24p128

URL: http://dx.doi.org/10.5539/ijbm.v7n24p128

\begin{abstract}
Working on entrepreneurship bears special significance for country like Bangladesh where density of population is very high. It is really a great challenge for the country to accommodate such a large population. Developing the determinants on entrepreneurial intention can take the country a step ahead for the improvement of entrepreneurial culture. Nurturing such culture will flourish entrepreneurship development which can create scope for accommodating substantial number of people. In this backdrop, this study has tested a causal model in context of business students of Bangladesh to identify what determines their intentions to be an entrepreneur. For this purpose data were collected from the business students studying at Bachelor and Master Level in public and private universities. From the previous literature, variables like risk taking, locus of control, need for achievement, autonomy, challenges, security of job, environment for staring business and entrepreneurial education offered by Universities have been tested using multiple regression model. The model results show tendency of taking risk, need for achievement, education and environment for starting business, job security are statistically significant in determining the intention of students where except job security, variables are found positively related.
\end{abstract}

Keywords: entrepreneurial intention, business students, job, environment

\section{Statement of the Problem}

\subsection{Background}

In this twenty first century organizations are putting immense emphasize on creativity and innovation in every sphere of operation (Delmar and Davidsson, 2000). This is due to the fact that-in this hyper competitive market only creative and differentiated ideas can ensure distinctive competencies for firms and thus can be resulted in long term sustainable success.

While the organizations are striving for organizational intrapreneurism in every field at the same time countries are also focusing on developing entrepreneurs in order to foster economic growth and development (Naffziger et al., 1994). Entrepreneurs play important role for the growth and development of an economy as through entrepreneurship development few things automatically comes. Those are employment, enhancement of quality of life, social up gradation, reduction of poverty and so on (Scott and Twomey, 1988). The immense significance of developing entrepreneurship is even greater if we consider the scenario of developing country like Bangladesh as agriculture base developing countries always try to shift its economic focus from agriculture to business for the creation of more job opportunities. Entrepreneurship contributes development of an economy by creating new markets, new industries, new technology, new jobs and net increases in real productivity (Behave, 1994).

Thus, it is obvious that there is very few replacement of entrepreneurship for fostering and triggering economic development (Aldrich and Wiedenmayer, 1993). Then, the important bottom line from this just catch the attention is that how to foster entrepreneurship and what are the factors and forces that does trigger the entrepreneurship development process. This is an important area of global research on entrepreneurship and innovation as it focuses on the root causes behind people's motivation of becoming entrepreneurs (Summers, 1998 and Delmar and Davidsson, 2000). The immense significance of this study rooted into that area. It has uncovered the determining factors that influence the entrepreneurial intention of potential entrepreneurs and future business leaders in the form of business students of different prominent universities of Bangladesh. 


\subsection{Research Question}

What are the determinants of entrepreneurial intentions of business students?

\subsection{Rationale}

Bangladesh is a densely populated country of the world. Its huge population could have been its resources that could lead the country to enjoy competitive advantage over others. But in reality this population is seen here as burden due to the scarcity of sufficient scope where their labor could be employed. Only way is to get relief from the situation is to create ample employment opportunities where entrepreneurs can contribute significantly. Therefore, priorities are being given on the development of entrepreneurship. Entrepreneurship and small businesses have been designated as the "engines of growth" because of their job creating phenomenon, not only in the advance countries (Birch 1987; Dimo 2007) but also developing and privatizing economies across the global' Governments and policymakers have become keenly aware of the economic development benefits that are derived from the establishment and growth of entrepreneurial endeavors (Khan et.al, 2003). This study has intended to identify the factors affect entrepreneurial development of students earning degree in the areas of business.

Bangladesh is one of the emerging developing countries where large numbers of students are pursuing degrees in the areas of business. According to the statistics of University Grand Commission, the number of student entered in business and commence education was 22,144 in 2010. It generally expected that being educated in this area, students will be encouraged to pursue the path to be a successful entrepreneur. Therefore, it is important to understand what factors affect their entrepreneurial intention. This research has been conducted to address this issue also.

\section{Literature Review and Conceptual Framework}

\subsection{Introduction}

The general definition of the relationship between different determining factors and entrepreneurial intention has altered a lot in recent years. In western countries researchers are trying hard to adopt and get a successful entry into the new structure of this relationship (Brockhaus, 1982). It is widely believed and also outcomes of number of research papers-that there are different situational, psychological, environmental and also personal issues and factors that influence people to become entrepreneur (Bateman and Crant, 1993). According to the basic scientific outcome in the field of psychology and organization behavior-modern students and pupils somehow seek more self control and decision making authority than the old compatriots used to do (Krueger, 1993). However, the case is not of the similarity in every situation. It does get varied from country to country region to region or society to society.

Going deep into this field of academic research is always worth undertaking as entrepreneurship development is always considered as one of the major field of economic and industrial development of every country. Hence, it is essential to get an insight into the relationship of this concept and find out ways to develop and enhance more entrepreneurial culture into the set up (Scott and Twomey, 1988). Prior to evaluate the important implication of the study it is important to get an overview and theoretical understanding of surrounding and relevant issues and concepts. In this study the same thing has been done from this point onwards.

\subsection{Definition of Core Concepts}

\subsubsection{Entrepreneurship}

Entrepreneurship is the practice of starting new organizations, particularly new businesses generally in response to identified opportunities. According to Schumpeter, Entrepreneurship is the "spirit" to innovate. Knight, Drucker, Hart, Stevenson and Dial have defined entrepreneurship as risk taking behavior which has been carried out for future benefit and gaining independence and self-control (Parker, 2004). An entrepreneur is a person who undertakes and operates a new enterprise or venture, and assumes some accountability for the inherent risks. Therefore, virtually entrepreneurship is equivalent to starting new businesses (Wilberforce and Fleming, 2001). We can provide a broad and comprehensive definition of entrepreneurship in the following way: Entrepreneurship is the process of identifying opportunities in the market place; marshalling resources pursue the opportunities and committing actions and resources necessary to exploit the opportunities for long term personal gain (Parker, 2004 and Gartner, 1989). The creative and functional definition of entrepreneurship defined it as a human-creative act that builds something of value from practically nothing. It is the pursuit of opportunity regardless of the resources, or lack of resources, at hand. It requires a vision and the passion and commitment to lead others in the pursuit of that vision. It also requires a willingness to take calculated risks (Boyd and Vozikis, 1994). 


\subsubsection{Intention}

Human beings are the best creature of almighty and thus excel themselves over other creature in certain important areas. One area certainly is their ability to think and judge phenomenon and also provide judgmental opinion by concisions and judicious thinking (Liñán, 2004). Alongside that human beings tend to differ genetically as far as their preferences are concern. This notion certainly gives the birth of their ability to get attracted towards certain things while also distracted and demotivated by certain factors and forces (Delmar and Davidsson, 2000). This motivation and demotivation about objects, issues, feelings, beliefs and also many other verbal and nonverbal expressions commonly referred as intention which may be positive or negative in both ways (Bird, 1988). Intention is an individual's specific propensity to perform an action or a series of actions. It is the result of conscious thinking that directs behavior (Parker, 2004). Bird (1998) defines intention is the state of mind directing a person's attention and action towards self-employment as opposed to organizational employment.

\subsubsection{Entrepreneur and Entrepreneurial Intention}

The origin of the concept "Entrepreneur" lies in 17th century in France - as an individual commissioned to undertake a particular commercial project by someone with money to invest. In its earlier stages this usually meant an overseas trading project. Such projects were risky, both for the investor (who could lose money) and for the entrepreneur (who could lose a lot more) (Liñán, 2004 and Tkachev and Kolvereid, 1999). Although the term was used before Cantillon, it is clear that Cantillon was the first to offer a clear conception of the entrepreneurial function as a whole (in 1755). He defined "Entrepreneur" as a person who took an active risk-bearing role in pursuing opportunity. Behaviorists' such as Max Weber (1930) and David C. McClelland (1961): tried to understand entrepreneur as a person. They mainly concentrated on creativity and intuitive characteristics of entrepreneurs (Ronstadt, 1990 and Krueger et al., 2000). Entrepreneurs not are characterized by every action they take, but by a particular set of actions aimed at the creation of new wealth with their ventures. The Entrepreneur can be considered as: a manager undertaking an activity - i.e. in terms of the particular tasks they perform and the way they undertake them, an agent of economic change - i.e. in terms of the effects they have on economic systems and the changes they drive, an individual - i.e. in terms of their psychology, personality and personal characteristics (Bird, 1988).

Entrepreneurial intention is the proclivity of starting a new business. Krueger (1993) defines entrepreneurial intentions as a commitment to starting a new business. This intention indicates potentiality of an entrepreneur to start business in the future.

\subsubsection{Factors Affecting Entrepreneurial Intention}

From the substantial number of previous research on entrepreneurial intention it has been identified that three factors dominate entrepreneurial intension. One is his or her demographic profile that includes age, sex, previous experience, influence of role model. Second one is personality traits that include self-efficacy, confidence, autonomy, locus of control, risk taking tendency, professional attraction. Third factor is contextual that includes education and environment (Wärneryd, 1988).

According to trait theory of entrepreneurship- entrepreneurial intentions are dictated by some particular traits. Those are: High need for achievement; which means a need to always achieve new bold goals, risk taking propensity; which defined as a willingness to take financial risks, tolerance for ambiguity; which refers no fear of the unknown, innovation; which is an ability to create new or modify existing business concepts, intuition; which is synonymous of make decisions based on 'gut feelings', internal locus of control which is synonymous to a belief that the future is determined by their own actions and also proactiveness; which is making plans for events before they occur (Boyd and Vozikis, 1994).

According environmental approach theory-Choice of Entrepreneurship is related to external factors beyond the individual's control, seen as a cultural phenomenon, education and experience, family background. Ahmed et al (2010) worked on some factors to identify the determinants of entrepreneurial intentions among students in Pakistan. They investigated the effect of innovation, education, family background and gender difference on creating intentions. They found innovativeness and family business experience are related with entrepreneurial intention.

Contingency theory of entrepreneurship suggests that people do not become entrepreneur willingly rather situations or contingencies force them to become so. In such situations they have some motivations for becoming entrepreneurs in certain situations (Shaver and Scott, 1991). (Tubbs and Ekeberg, 1991) identified different types of refuges whose entrepreneurial intentions are get dictated due to different posing situations. Those are Foreign 
refugees: people escaping political or religious persecution or to seek economy with greater opportunities, Corporate Refugees: people dissatisfied with corporate environment, Parental refugees: children of self-employed parents, Feminist Refugees: women who feel discriminated against by supervisors, peers, education system, corporate world, Social Refugees: people who do not agree with certain aspects of their society -- usually start a business tied to their hobby or craft and Educational Refugees: young people who drop out of the education system -- feel restricted or because of circumstances

According to McClelland's Achievement Motivation Theory few people want to become entrepreneurs because they possess more needs of certain important aspects than normal people do. McClelland and colleagues studied the behavioral effects of three needs: need for achievement, need for power and need for affiliation (Honig, 2004). On the other hand-motive acquisition theory suggests that mentality and personality of people are not nature gifted. Those are flexible with the changing situation. An individual can be influenced and motivated towards a goal by changing his thinking, mentality, attitude etc. It is possible by different types of training like: motivate vocational choices, technical, managerial, security, creativity, autonomy etc (Guzmán and Santos, 2001).

\subsection{Relationship between Entrepreneurial Intention and Various Determinants}

Relationships between personality traits and entrepreneurial behavior are frequently discussed in entrepreneurship research. Nishantha (2009) examined effect of personality traits on motivation of students to select entrepreneur career. He indentified that need for achievement and risk taking propensity are highly contributed for developing positive attitude toward entrepreneurship but the relationship between internal locus control and entrepreneurial attitude is not significant. Urbano (2008) investigated the impact of perceived desirability (social norms and attitude) and perceived feasibility (self-efficacy) on entrepreneurial intentions. Tong, Tong, Loy (2011) worked on only two personality traits including need for achievement and desire for independence. They ignored important traits like risk taking propensity, self-efficacy, and autonomy. Along with personality traits, they examined the contribution of family background and subjective norms to generate entrepreneurial intention among students. Internal factors like willingness to take risks need for independence and locus of control are studied by Franke and Luthje (2004). They also investigated some external factors like market, education, training, network, society, inspiration likely to affect student intention to be an entrepreneur.

It is recognized that situational variables are very important in the decision to start a business; it is the convergence of attitudes and situational factors that leads to business start-ups (Shapero, 1982). Situational variables like environment, educations, network, and subjective norms have been studied in previous researches to determine the intention of entrepreneurs. Kennedy et. al (2003) found subjective norms positively related with entrepreneurial intentions. Keat, Selvarajah, Meyer (2011) examined relationship between entrepreneur education and inclination toward entrepreneurship. They also examined some demographic characteristics and business background. They identified two entrepreneurship variables, i.e university roles to promote entrepreneurship and entrepreneurial curriculum and content along with gender, working experience, and mother's occupation are statistically significant.

\subsection{Earlier Research Works and Contribution of this Study in Adding Value to Existing Scientific Literature}

Entrepreneurial intentions are diverse in nature across cultures and different ethnicity. While in some culture it is the symbol of creativity and individualism in other areas it is found to be judged as the incapability of going with the mainstream of the society (Lee and Wong, 2004). However, the negativity towards entrepreneurs has seemed to be altered greatly in recent years as people bolstered by the immense success stories of entrepreneurs like Bill Gates, Steve Jobs or Mark Jukerberg. As a result it also has resulted into positive mood as far as the societal preferences are concern (Liñán, 2005 and Boyd and Vozikis, 1994). The cases in western societies are totally positive and in fact entrepreneurs are even obtained pole positions in societal prestige and recognition chart. This notion is also quickly spreading in Asian and African Societies very quickly and as a result entrepreneurial intention now a day's gaining immense importance across educational and business set-up (Peterma and Kennedy, 2003 and Bagozzi et al., 1989).

Hence, entrepreneurship and innovation in business operation always considered as the life blood for obtaining competitive advantages, many academicians and researchers have undertaken numerous scientific works in this field (Autio et al., 1997, Liñán, 2004, Tkachev and Kolvereid, 1999 and Veciana et al., 2005). The main focus on these scientific works varies over the years but the goal always has been on finding out new ways of entrepreneurship development and also making sure that such development can contribute towards development of corporation and also economic and social development of countries (Cooper, 1993). Thus, entrepreneurial intention always catches significant attentions of entrepreneurial and innovation research as it is essential to 
know the factors that instigate and motivate people to become entrepreneurs (Carroll and Mosakowski, 1987 and Gartner, 1985).

Ronstadt (1990), Krueger et al., (2000) and Delmar and Davidsson (2000) has identified that entrepreneurial intention mainly comes from psychological and situational dissatisfaction as well as positive motive towards accomplishments. Similar notion has also been achieved from the studies of (Shane et al., 1991, Blanchflower et al., 2001 and Johnson, 1990) as well. In addition they also have identified that such intentions varies for people of different ages. Entrepreneurs found to be possessed with some specific traits and those traits are found to be more or less common in every successful entrepreneur. Bird (1993), Reynolds (1992) and Gartner (1989) have conducted research on fifty successful entrepreneurs and come with some school of entrepreneurial traits which is very evident from their way of works and business development pattern.

Kolvereid and Moen (1997) advise researchers to include measures of attitudes, norms and perceived behavioral control, since these factors have been found to be related to entrepreneurial intentions. Wang, Lu, Millington (2011) investigated the determinants of entrepreneurial intention among two groups of college student using a model. They indentified positive impact of perceived desirability and perceived feasibility on entrepreneurial intention. Previous research observed positive impact of entrepreneurial personality but they found the impact indifferent. Golard and Saleh (2011) investigated the impact of educational support, structural support, informal network and formal network on entrepreneurial intentions. They confirmed the key role of education for the development of entrepreneurial intentions. They concluded structural support may affect intention. But they did not find the effect of informal and formal network affecting intentions of students.

From the earlier established scientific research works about entrepreneurial intention and sky-high importance of entrepreneurship development-it is obvious that this field of research is a very important in modern business education and always worth taking (Wärneryd, 1988 and Wilberforce and Fleming, 2001). The case is even more important when the concern is about future generation as they will be the business leader in future and will be the drivers of development (Parker, 2004 and Gartner, 1989). The immense importance of this study rooted there. This has been uncovered the major determinant of entrepreneurial intentions of business students in Bangladesh and thus will help to establish polices in the areas of entrepreneurship development policy, educational restructuring and also alteration in the entrepreneurial community up gradation system in the country.

\subsection{Research Hypothesis}

$\mathrm{H}_{1}$ : There is a relationship between risk taking tendency and entrepreneurial intention of students

$\mathrm{H}_{2}$ : There is a relationship between locus of control and entrepreneurial intention of students

$\mathrm{H}_{3}$ : There is a relationship between need for achievement and entrepreneurial intention of students

$\mathrm{H}_{4}$ : There is a relationship between autonomy of occupation and entrepreneurial intention of students

$\mathrm{H}_{5}$ : There is a relationship between occupational challenges and entrepreneurial intention of students

$\mathrm{H}_{6}$ : There is a relationship between security in occupation and entrepreneurial intention of students

$\mathrm{H}_{7}$ : There is a relationship between environment for starting business and entrepreneurial intention of students

$\mathrm{H}_{8}$ : There is a relationship between education and entrepreneurial intention of students

\section{Methodology}

\subsection{Population and Sampling}

In this study population is all the students study in business and commerce in all universities including public and private. There are 89 universities where 55 are private and rest is public in Bangladesh. Most of the universities offer degrees in business and commerce. According to the latest student statistics of UGC, total students in business and commerce were 22,144 in 2010.

\subsection{Data Collection Methods}

This is a survey type of research conducted based on the responses collected from the students studying at graduation and master level using structured questionnaires. The survey focuses on the students of business and commerce only. A total of 520 students were selected on convenience basic from various public and private universities located in Dhaka, Rajshahi, Khulna, Sylhet and Kustia. Students were from different major areas including management, marketing, accounting and information system, hospitality and tourism management, and finance. 


\subsection{Research Instruments}

The questionnaire was adopted form various previous sources and used to collect the data. The variables selected in this study are risk taking, locus of control, need for achievement, autonomy and control, challenges and opportunities related to job, job security, environment for starting business and education. Items selected to measure these variables were adopted form previous studies and literature conducted on students entrepreneurial intention. The final questionnaire consists of six parts. Part I includes questions to collect demographic information and educational back ground of respondents. Part II aims at measuring respondent intention to be involved in entrepreneurial function. Part III has been designed to measure personality traits of respondents which determine the propensity of an individual to be an entrepreneur. This part involves 22 items. Part IV requests respondents to provide their views about their occupational attractions based on autonomy and authority of job, its challenges and opportunities as well as security. Part V includes items that provide information about respondents' views about the environmental aspects that inspire one to start business as well as how education contributes to build up their intention. Last part includes only two items request respondent to provide information about their family background regarding entrepreneurial linkage. All the variables were measured using five point likert scale with level $1=$ strongly disagree and $5=$ strongly agree. Data have been analyzed using correlation and regression as well as descriptive statistical techniques. Reliability statistics has been applied to measure data reliability.

\section{Findings and Analysis}

Table 1 shows that the independents variables explain $31.8 \%(\mathrm{R}$ square $=.381)$ variation of independent variable. This table also indicates that risk taking tendency, need for achievement, job security, environment for starting business and education are statistically significant in determining the intention of business students to be entrepreneur in Bangladesh. The model results show that student tendency for taking risk, their need for achievement, job security, education on entrepreneurship offered by universities, are the strongest determinants followed by environment created by the government for starting a business.

Durbin-Watson statistic shows the serial correlation of residuals which is 1.98 , the value falls within the acceptance range (1.5 and 2.5). This indicates that there is no auto correlation problem in the data The F-value is found to be significant at $5 \%$ significance level (sig. $\mathrm{F}=.000$ ). This concludes that the regression model used in this study is adequate or in other words, the model was fit. (Table 1)

Table 1. Regression statistics

\begin{tabular}{lcc}
\hline Variable & Standardized Beta & Alpha \\
\hline Risk Taking & $.312^{* *}$ & .763 \\
Locus of Control & .004 & .785 \\
Need for Achievement & $.215^{* *}$ & .628 \\
Autonomy in Jobs & .092 & .806 \\
Challenges in Job & -.015 & .709 \\
Job Security & $-.126^{*}$ & .779 \\
Environment for Starting Business & $.104^{*}$ & .832 \\
Education & $.116^{*}$ & .886 \\
R Square & .318 & \\
F Value & $29.01 * *$ & \\
Durbin-Watson & 1.98 & \\
\hline$* * \mathrm{P}<.001, * \mathrm{P}<.05$ & &
\end{tabular}

Table 2 describes the collinearity statistics. The Variance Inflation Factors (VIF) and tolerance fall within the acceptance range, $(\mathrm{VIF}=1-10$, tolerance $=0.1-1.0)$. This means that there is no multi-co linearity problem in the regression model used for this study. 
Table 2. Collinearity statistics

\begin{tabular}{lcc}
\hline Variables & Tolerance & VIF* \\
\hline Risk Taking & .702 & 1.42 \\
Locus of Control & .575 & 1.74 \\
Need for Achievement & .479 & 2.09 \\
Autonomy in Jobs & .488 & 2.05 \\
Challenges in Job & .470 & 2.13 \\
Job Security & .766 & 1.3 \\
Environment for Starting Business & .774 & 1.29 \\
Education & .782 & 1.27 \\
\hline
\end{tabular}

*Variance Inflation Factor

\section{Results and Discussion}

The basic objective this research study and scientific research works was intended toward detecting the relevant factors that instigate and thus work as key influencing variables of entrepreneurial intention of the business students in Bangladesh. In order to do so few basic and important variables were derived from the through and in-depth review of the literature and also the self-conceptualization and understanding of the concerned researchers. Eight factors in the form of risk taking, locus of control, need for achievement, autonomy in jobs, challenges in job, job security, environment for starting a business and education were examined to assess the relationship between entrepreneurial intention and these important independent variables. As par the selected hypothesis risk taking, locus of control, need for achievement, autonomy in jobs, environment for starting a business and education have positive correlation. While risk taking, need for achievement, and environment for starting a business and education has been found to have strong positive correlation job security has been possessed with strong negative correlation which is very significant and logical outcome of the study. Alongside those challenges in job has slightly negative correlation with entrepreneurial intention which is bit of surprising result.

These entire outcomes of this current study signify important implications and understandings. First, of all this study has obtained that entrepreneurial intention is negatively correlated with job security. This is a common notion as people who possess strong desire to be entrepreneurs are mainly accelerated by their inner force of becoming independent. Therefore these people's posses string tenacity to ward risk taking and seldom care a lot a secured and safe life. Therefore, this evidence of the outcome is consistent. Alongside that this notion is also supported by the ideas of the famous entrepreneurial experts like Joseph Schumpeter or Peter Drucker.

The outcome also represents that entrepreneurial intention is positively correlated with vital phenomenons like risk taking, need for achievement, environment for starting for a new business and education. Risk taking and innovativeness are defined to be the dream combination or generating entrepreneurship activities in the real life world. According the Landaus (2002) the dream combination and deadly combination of moderating risk taking and high degree of innovativeness is always the lethal weapon for starting as well as sustaining a new business venture in term of entrepreneurship. So, those people who are risk takers bound to have more entrepreneurial intention than normal ones which is also supported by the outcome of this paper. McClelland's (1965) famous need theory suggests that there are three kinds of need, need for achievement, affiliation and power. A lot of scientific research paper outlined that high need achievers are tend to be entrepreneurs. Thus there should be strong correlation in between those variables and this is also quite evident in this research. Entrepreneurial educational and friendly environment is always requiring being conducive for entrepreneurship development and it is always required and thus create base for entrepreneurship development. A significant correlation score of this study is also evident in this case.

\section{Conclusion and Implication}

As a fast developing economy of immense potential, Bangladesh is striving hard to create an strong base of manpower into its armory who will be capable enough to carry out the development activities. Creativity, innovation, entrepreneurship, out of the box thinking is the gist of modern development and also western countries are already been able to develop their entire education system centered on this theme. This is due to the 
fact that only creative people are the hope of twenty first century were burning issues like poverty, global warming, terrorism are threatening the fate of human civilization. Therefore, entrepreneurship development in the entire sphere of fields including business, science, and society are of huge significance in this modern time. Bangladesh is certainly not out of this and entrepreneurs in the entire field are of immense vitality for the country in various fields.

Therefore, research studies in the field of economics of innovation and entrepreneurship development is of huge significance for country specially for making long term strategic planning for the countries development which is also needed to be well integrated and rooted into the entire educations system of the country. The basic objective of this study is rooted there. It has been able to uncover the basic important ingredients of entrepreneurial intention of the business students of the country. The outcome reveals that there are few major variables that trigger entrepreneurship and thus those factors required to be boosted in the education and social set up of the country. This study will immensely help the policy maker into setting such entrepreneurship friendly education system and social structure which will carry the development activities of the nation in upcoming years.

\section{References}

Ahmed et al. (2010). Determinants of Students' Entrepreneurial Career Intentions: Evidence from Business Graduates. European Journal of Social Sciences, 15(2), 14-22.

Aldrich, H., \& Wiedenmayer G. (1993). From Traits to Rates: an Ecological Perspective on Organizational Foundings. Advances in Entrepreneurship, Firm Emergence, and Growth, 1, 145-196.

Autio, E., Keeley, R. H., Klofsten, M., \& Ulfstedt, T. (1997). Entrepreneurial intent among students: Testing an intent model in Asia, Scandinavia and USA. Frontiers for Entrepreneurship Research Conference, Babson College.

Bagozzi, R., Baumgartner, H., \& Yi, Y. (1989). An investigation into the role of intentions as mediators of the attitude-behaviour relationship. Journal of Economic Psychology, 10, 35-62. http://dx.doi.org/10.1016/0167-4870(89)90056-1

Bateman, T. S., \& Crant, J. M. (1993). The proactive component of organizational behavior: A measure and correlates. Journal of Organizational Behavior, 14, 103-118. http://dx.doi.org/10.1002/job.4030140202

Behave, M. P. (1994). A process model of entrepreneurial venture creation. Journal of Business Venturing, 9 , 223-249. http://dx.doi.org/10.1016/0883-9026(94)90031-0

Birch, D. (1987). Job Creation in America. New York, NY: The Free Press.

Bird, B. (1993). Demographic Approaches to Entrepreneurship: the Role of Experience and Background. Advances in Entrepreneurship, Firm Emergence, and Growth, 1, 11-48.

Bird, B. (1998). Implementing Entrepeneurial Ideas: The Case for Intention. Academy of Management Review, $13,442-453$.

Blanchflower, D. G., Oswald, A., \& Stutzer, A. (2001). Latent entrepreneurship across nations. European Economic Review, 45, 680-691. http://dx.doi.org/10.1016/S0014-2921(01)00137-4

Boyd, N. G., \& Vozikis G. S. (1994). The Influence of Self-Efficacy on the Development of Entrepreneurial Intentions and Actions. Entrepreneurship Theory \& Practice, summer, 63-77.

Brockhaus, R. H. Sr. (1982). The Psychology of Entrepreneurship. In C.A. Kent, D.L. Sexton \& K.H. Vesper (eds.), The Encyclopedia of Entrepreneurship. Englewood Cliffs, NJ.: Prentice-Hall.

Carroll, G. R., \& Mosakowski, E. (1987). The career dynamics of self-employment. Administrative Science Quarterly, 32, 570-589. http://dx.doi.org/10.2307/2392884

Cooper, A. C. (1993). Challenges in predicting new firm performance. Journal of Business Venturing, 8(3), 241-253. http://dx.doi.org/10.1016/0883-9026(93)90030-9

Delmar, F., \& Davidsson, P. (2000). Where do they come from? Prevalence and characteristics of nascent $\begin{array}{lllll}\text { entrepreneurs. Entrepreneurship and Regional Development, } & 12(1), & 1-23 .\end{array}$ http://dx.doi.org/10.1080/089856200283063

Dimo, D. (2007). From Opportunity Insight to Opportunity Intention: Impact of Person-Situation Learning $\begin{array}{llll}\text { Match. } & \text { Entrepreneurship: } \quad \text { Theory and }\end{array}$ http://dx.doi.org/10.1111/j.1540-6520.2007.00188.x 
Gartner, W. B. (1985). A conceptual framework for describing the phenomenon of new venture creation. Academy of Management Review, 10, 696-706.

Gartner, W. B. (1989). Some Suggestions for Research on Entrepreneurial Traits and Characteristics. Entrepreneurship Theory \& Practice, Fall, 27-37.

Gartner, W. B. (1989). Who is an entrepreneur? is the wrong question. Entrepreneurship Theory and Practice, 13(4), 47-68.

Gelard, P., \& Saleh, K. E. (2010). Impact of some contextual factors on entrepreneurial intention of university students. African Journal of Business Management, 5(26), 10707-10717.

Guzmán, J., \& Santos, F. J. (2001). The booster function and the entrepreneurial quality: an application to the province of Seville. Entrepreneurship and Regional Development, 13(3), 211-228. http://dx.doi.org/10.1080/08985620110035651

Honig, B. (2004). Entrepreneurship education: toward a model of contingency-based business planning. Academy of Management Learning and Education, 3(3), 258-273. http://dx.doi.org/10.5465/AMLE.2004.14242112

Johnson, B. R. (1990). Toward a Multidimensional Model of Entrepreneurship: The Case of Achievement Motivation and the Entrepreneur. Entrepreneurship Theory \& Practice, Fall, 39-54.

Keat, O. Y., Selvarajah, C., \& Meyer, D. (2011). Inclination towards entrepreneurship among university students: An empirical study of Malaysian university students. International Journal of Business and Social Science, 2(4), 206-220.

Kennedy, J., Denman, D. J., Renfrow, D. P., \& Watson, D. B. (2003). Situational factors and entrepreneurial intentions. 16th Annual Conference of Small Enterprise Association of Australia and New Zealand, pp. $1-12$.

Khan, Jahangir H., Biswas, Budha D., \& Ahmed, N. (2009). Extrinsic and intrinsic determinants of entrepreneurial growth of Bangladesh: An empirical examination. RMUTT Global Business and Economics Review, 4(2), 1-24.

Kolvereid, L., \& Moen, O. (1997). Entrepreneurship among business graduates: does a major in entrepreneurship make a difference? Journal of European Industrial Training, 21(4), 154-162. http://dx.doi.org/10.1108/03090599710171404

Krueger, N. F. (1993). The impact of prior entrepreneurial exposure on perceptions of new venture feasibility and desirability. Entrepreneurship Theory and Practice, 18(1), 5-23.

Krueger, N. F. Jr. (1993). The impact of prior entrepreneurial exposure on perceptions of new venture feasibility and desirability. Entrepreneurship Theory and Practice, 18(3), 91-104.

Krueger, N. F., Reilly, M. D., \& Carsrud, A. L. (2000). Competing models of entrepreneurial intentions. Journal of Business Venturing, 15(5/6), 411-432. http://dx.doi.org/10.1016/S0883-9026(98)00033-0

Lee, S. H., \& Wong, P. K. (2004). An exploratory study of technopreneurial intentions: a career anchor perspective. Journal of Business Venturing, 19, 7-28. http://dx.doi.org/10.1016/S0883-9026(02)00112-X

Liñán, F. (2004). Intention-based models of entrepreneurship education. Piccolla Impresa/Small Business, 3 , 11-35.

Liñán, F. (2005). Development and validation of an Entrepreneurial Intention Questionnaire (EIQ). IntEnt05 Conference, Guildford (United Kingdom), pp. 10-13.

Naffziger, D. W., Hornsby J. S., \& Kuratko D. F. (1994). A Proposed Research Model of Entrepreneurial Motivation. Entrepreneurship Theory \& Practice, Spring, 29-42.

Nishantha, B. (2009). Influence of Personality Traits and Socio-demographic Background of Undergraduate Students on Motivation for Entrepreneurial Career: The Case of Sri Lanka. Euro Asia Management Studies Association (EAMSA) Conference held on 5th December 2008 at Doshisha Business School, Kyoto, Japan.

Parker, S. C. (2004). The Economics of Self-Employment and Entrepreneurship. Cambridge UK: Cambridge University Press. http://dx.doi.org/10.1017/CBO9780511493430

Peterman, N. E., \& Kennedy, J. (2003). Enterprise Education: influencing students' perceptions of

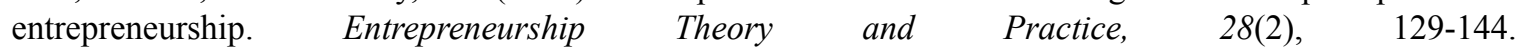
http://dx.doi.org/10.1046/j.1540-6520.2003.00035.x 
Reynolds, P. D. (1992). Sociology and entrepreneurship: Concepts and contributions. Entrepreneurship Theory and Practice, 16(2), 47-70.

Ronstadt, R. (1990). The educated entrepreneurs: a new era of entrepreneurial education is beginning. In Kent, C.A. (Ed.), Entrepreneurship education: current developments, future directions. Quorum Books, Westport.

Scott, M. G., \& Twomey D. F. (1988). The long-term Supply of Entrepreneurs: Students' Career Aspirations in Relation to Entrepreneurship. Journal of Small Business Management, 26, 35-13.

Shane, S., Kolvereid, L., \& Westhead, P. (1991). An exploratory examination of the reasons leading to new firm formation across country and gender. Journal of Business Venturing, 6, 431-446. http://dx.doi.org/10.1016/0883-9026(91)90029-D

Shapero, A., \& Sokol L. (1982). The social dimensions of entrepreneurship. Encyclopedia of Entrepreneurship. In C. A. Kent, D. L. Sexton and K. H. Vesper (eds.), Englewood Cliffs (pp. 72-90). N J, Prentice Hall.

Shaver, K. G., \& Scott, L. R. (1991). Person, process, choice: the psychology of new venture creation. Entrepreneurship Theory and Practice, 16(2), 23-45.

Summers, David, F. (1998). An empirical investigation of personal and situational factors that relate to the formation of entrepreneurial intentions. Doctoral dissertation, University of North Texas, Ann Arbor, MI : UMI Dissertation Services.

Tkachev, A., \& Kolvereid, L. (1999). Self-employment intentions among Russian students. Entrepreneurship and Regional Development, 11, 269-280. http://dx.doi.org/10.1080/089856299283209

Tubbs, M. E., \& Ekeberg, S. E. (1991). The role of intentions in work motivation: implications for goal-setting theory and research. Academy of Management Review, 14, 361-384.

Urbano, D., Guerrero, M., \& Rialp, J. (2008). The impact of desirability and feasibility on entrepreneurial intentions: A structural equation model. International Journal of Entrepreneurship Management, 4, 35-50. http://dx.doi.org/10.1007/s11365-006-0032-x

Veciana, J. M., Aponte, M., \& Urbano, D. (2005). University students' attitudes towards entrepreneurship: a two countries comparison. International Entrepreneurship and Management Journal, 1(2), 165-182. http://dx.doi.org/10.1007/s11365-005-1127-5

Wang, W, L., Wei, M., \& John, K. (2011). Determinants of Entrepreneurial Intention among College Students in China and USA. Journal of Global Enterpreneurial Research, 1(1), 35-44.

Wärneryd, K. E. (1988). The Psychology of Innovative Entrepreneurship. In: W. F. van Raaij, G. M. van Veldhoven \& K-E. Wärneryd (eds.), Handbook of Economic Psychology. Dordrecht: Kluwer.

Xue Fa T., David Yoon Kin T., \& Liang Chen L. (2011). Factors influencing entrepreneurial intention among University students. International journal of social sciences and humanity studies, 3(1), 487-496. 